\title{
ECOLOGY
}

\section{ФІТОТОКСИЧНІ ВЛАСТИВОСТІ ДЕЯКИХ ДЕРЕВНИХ РОСЛИН}

Дочент, к.б.н. Мегалінська Г. П., Дочент, к. б. н. Пакірбаєва Л. В., К. б. н. Білик Ж. I.,

${ }^{1}$ Даниленко $\Theta$. В.,

Гатальська . .*

Україна, Київ, Національний педагогічний університет імені М.П. Драгоманова

факультет педагогіки та психологіі

${ }^{1}$ Украӥна, Київ, Київська Мала академія учнівської молоді

DOI: https://doi.org/ 10.31435/rsglobal_ws/31032019/6404

\section{ARTICLE INFO}

Received: 12 January 2019

Accepted: 25 March 2019

Published: 31 March 2019

\section{KEYWORDS}

phytotoxic effects,

phyto-stimulating effect,

forest,

fitosenosis,

wood species.

\begin{abstract}
The results of the study of phytotoxic effects of water extracts from Pinus sylvestris L., Betula pendula Roth, Quercus robur L., Picea abies (L.) Karst. P. excelsa Link, Carpinus betulus L., Robinia pseudoacacia L., Populus tremula L., Crataegus submollis L. are presented. For a comparison of the phytotoxic activity of the investigated plants was used to measure the change in the intensity of the mitotic division, depending on the concentration of aqueous extraction of plant material (tangent trend curve of cytostatic activity). According to this parameter, the following row of phytotoxic activity of wood species can be ordered: Populus tremula, Betula pendula, Robinia pseudoacacia, Carpinus betulus, Acer platanoides, Tilia cordata, Pinus sylvestris. Water extract Quercus robur and Picea abies have discovered a phyto-stimulating effect. The results of the study allow us to discuss the possibility of introducing the parameter of the phytotoxicity coefficient to determine the allelopathic effect in the tree-tree system.
\end{abstract}

Citation: Мегалінська Г. П., Пакірбаєва Л. В., Білик Ж. І., Даниленко Є. В., Гатальська Є. О. (2019) Fitotoksychni Vlastyvosti Deiakykh Derevnykh Roslyn. World Science. 3(43), Vol.1. doi: 10.31435/rsglobal_ws/31032019/6404

Copyright: ( ) 2019 Мегалінська Г. П., Пакірбасва Л. В., $\quad$ Білик Ж. І., Гатальська Є. O. This is an open-access article distributed under the terms of the Creative Commons Attribution License (CC BY). The use, distribution or reproduction in other forums is permitted, provided the original author(s) or licensor are credited and that the original publication in this journal is cited, in accordance with accepted academic practice. No use, distribution or reproduction is permitted which does not comply with these terms.

Вступ. Однією з актуальних проблем лісознавства є вивчення взаємного впливу всіх компонентів лісових фітоценозів [5].

Дерева і кущі будь-якого лісового ценозу біологічно пов’язані між собою, впливають один на одного і на навколишнього середовище.

Академік Г.М. Висоцький охарактеризував поняття «ліс» у вигляді формули:

$$
\mathrm{S}=\mathrm{LGPH},
$$

де $\mathrm{S}$ - ліс (silva), L - дерево (lignum), G - середовище (gremium), P - вплив лісу на середовище (pertinentia), Н - вплив людини на ліс (Homo) [4].

Складова L включає взаємодію деревних рослин між собою та вплив деревостану на інші компоненти фітоценозу лісу.

Алелопатичний вплив або вплив біологічно активних сполук однієї рослини на ріст і розвиток іншої $\epsilon$ актуальним питанням, як теоретичного, так i практичного аспекту 
лісознавства. Для вивчення алелопатичного впливу одних рослин на інші найчастіше використовують такі тест-культури як Brassica juncea L., B. oleracea L., Lepidium sativum L., Sinapis alba L. [2] Класично алелопатичний вплив оцінюють за допомогою методик, описаних Райсом Е. [3], але для вивчення фітотоксичності, як компонента алелопатичної дії, найбільш валідним $є$ метод В.Б. Іванова та Є.Н. Бистрової, який базується на оцінюванні мітотичної активності клітин меристеми коренів рослин родини Гарбузових [1]. Автори цієї методики зазначають, що вона може застосовуватися не тільки для вивчення фітотоксичного впливу однісї рослини на іншу, але і для ідентифікації активних цитостатиків у медичній ботаніці [1]. Тому метою представленого дослідження було вивчення фітотоксичної (цитостатичної) дії таких деревних рослин: сосни звичайної (Pinus sylvestris L.), берези бородавчатої (Betula pendula Roth.), дубу звичайного (Quercus robur L.), липи серцелистої (Tilia cordata Mill.), клену звичайного, або гостролистого (Acer platanoides L.), ялини звичайної (Picea abies Mill), грабу звичайного (Carpinus betulus L.), білої акації, або робінії звичайної (Robinia pseudoacacia L.), осики звичайної (Populus tremula L.) відносно тестового об'єкту - огірка звичайного (Cucumis sativus L.) та обгрунтування можливості введення параметр коефіцієнт фітотоксичності для визначення алелопатичного впливу в системі «дерево-дерево».

Методи дослідження: методика оцінки цитостатичної активності водних екстрактів рослинної сировини В.Б. Іванова та Є.Н. Бистрової [1].

На нашу думку, сталість видового складу природних лісових насаджень пов'язана не лише 3 відповідністю абіотичних факторів, екологічним вимогам певних видів деревних рослин, але і біотичною взаємодією між рослинними організмами.

Результати дослідження представлені на графіках.

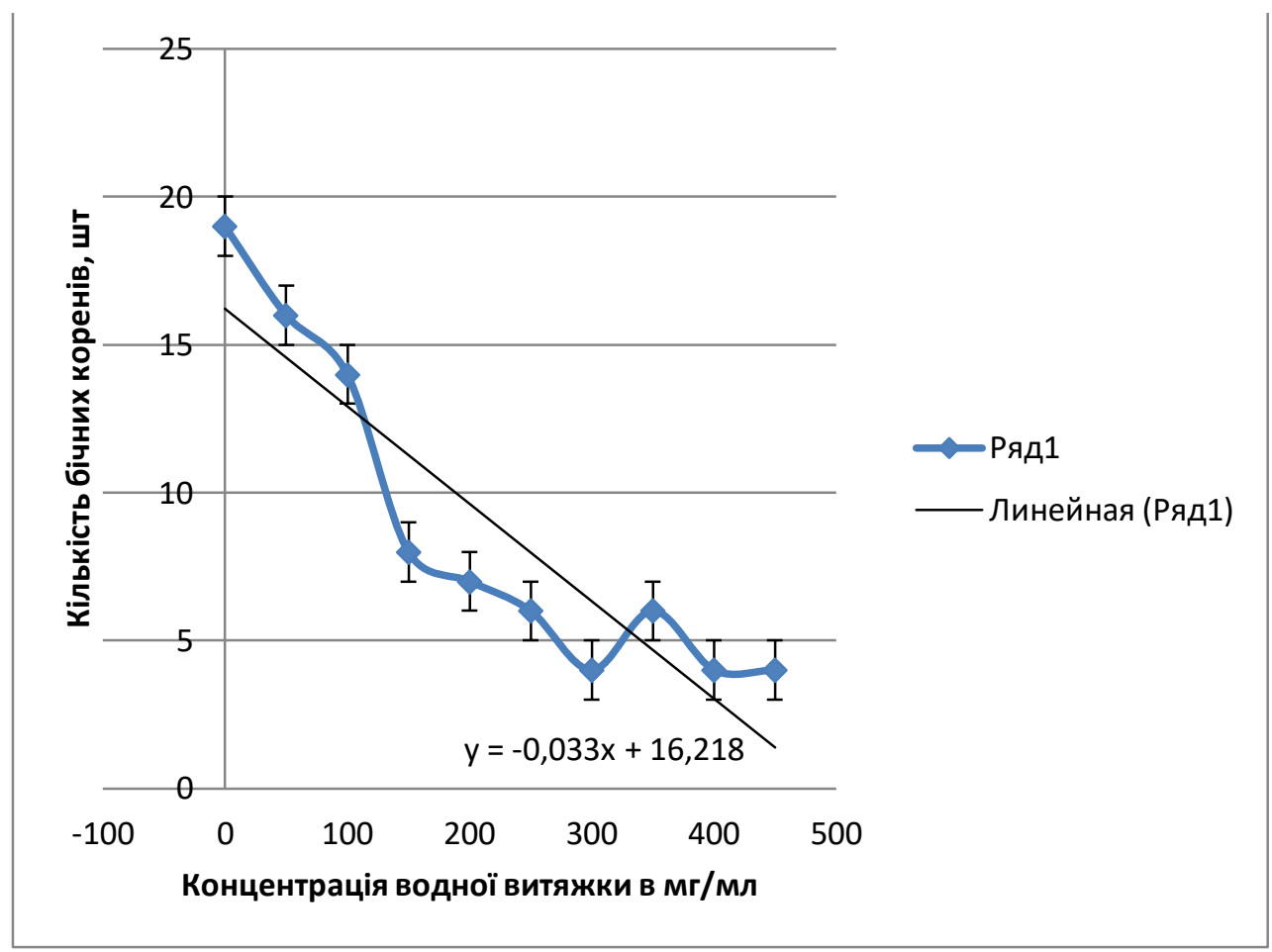

Рис. 1. Цитостатична активність водної витяжки осики звичайної

Відповідно до результатів експерименту водний екстракт 3 осики має властивості інгібітора проліферації і блокує утворення бічних коренів у пророслого насіння огірка практично при всіх розведеннях екстракту (Рис.1). 


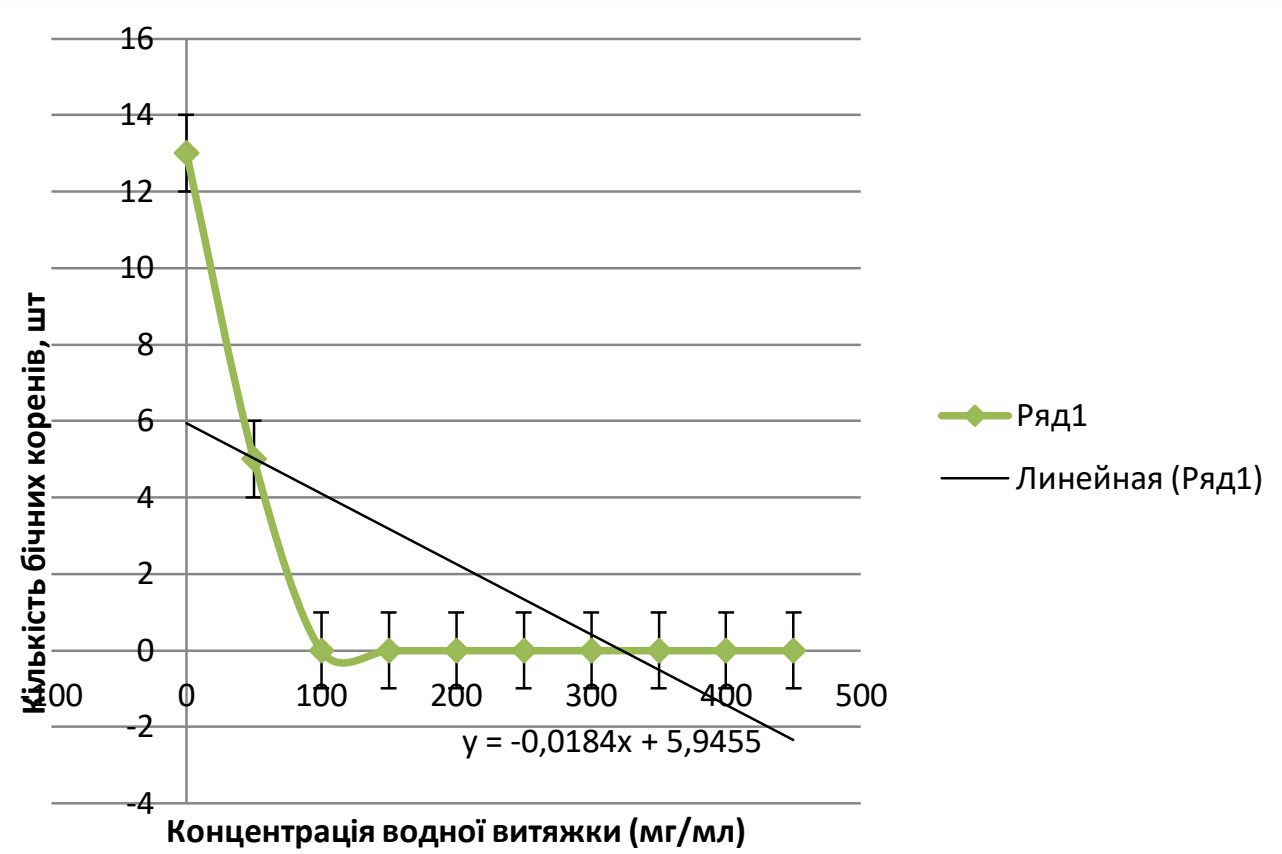

Рис.2. Цитостатична активність водної витяжки берези бородавчастої

Екстракт з берези бородавчатої має сильні цитостатичні властивості і повністю блокує утворення бічних коренів у пророслого насіння огірка практично при всіх розведеннях екстракту, починаючи 3 концентрації 100 мг/мл.

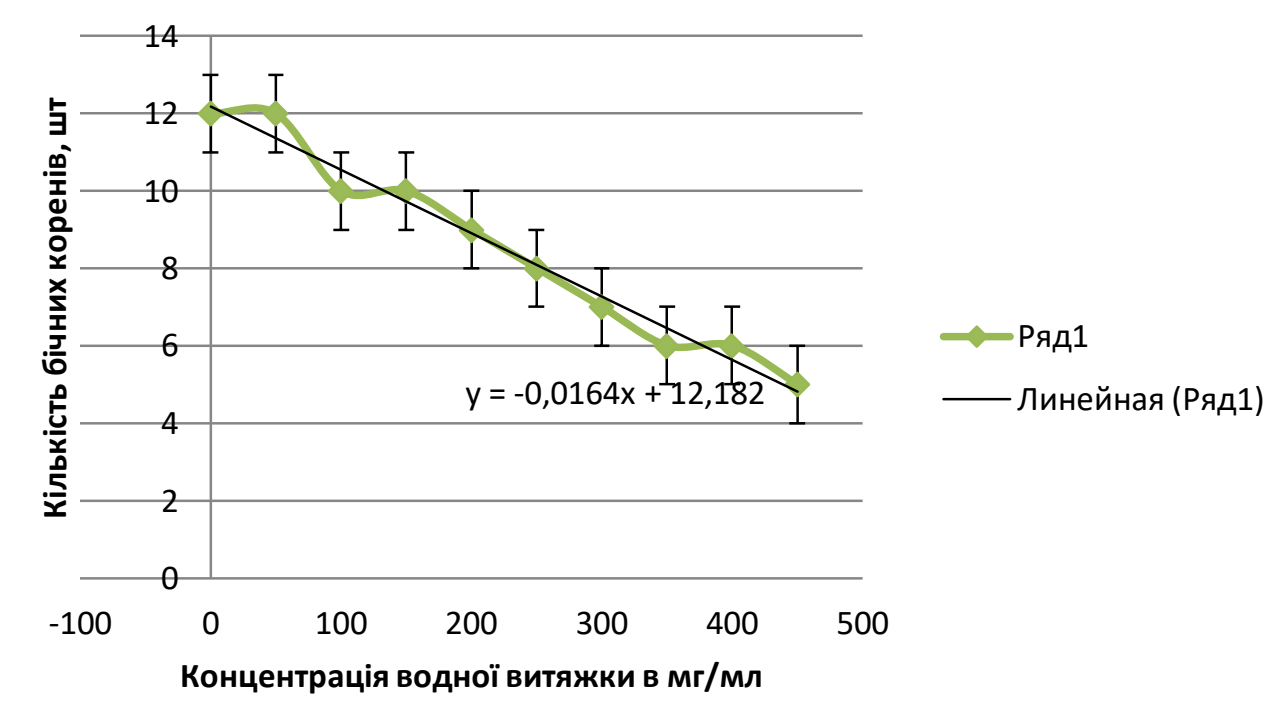

Рис.3. Цитостатична активність водної витяжки акації білої

Водний екстракт з білої акації має певні властивості інгібітора проліферації і блокує утворення бічних коренів у пророслого насіння огірка практично при всіх розведеннях екстракту (Рис. 3).

Водний екстракт з грабу звичайного демонструє ефект інгібітора проліферації (Рис. 4), подібні властивості характерні для водної витяжки клена гостролистого (Рис. 5)

Водний екстракт липи серцелистої стимулює утворення бічних коренів до концентрації 300 мг/мл, при підвищені концентрації спостерігається не значний інгібіювальний ефект (Рис. 6).

Екстракт сосни звичайної демонструє ефект стимулятора проліферації (Рис. 7). 


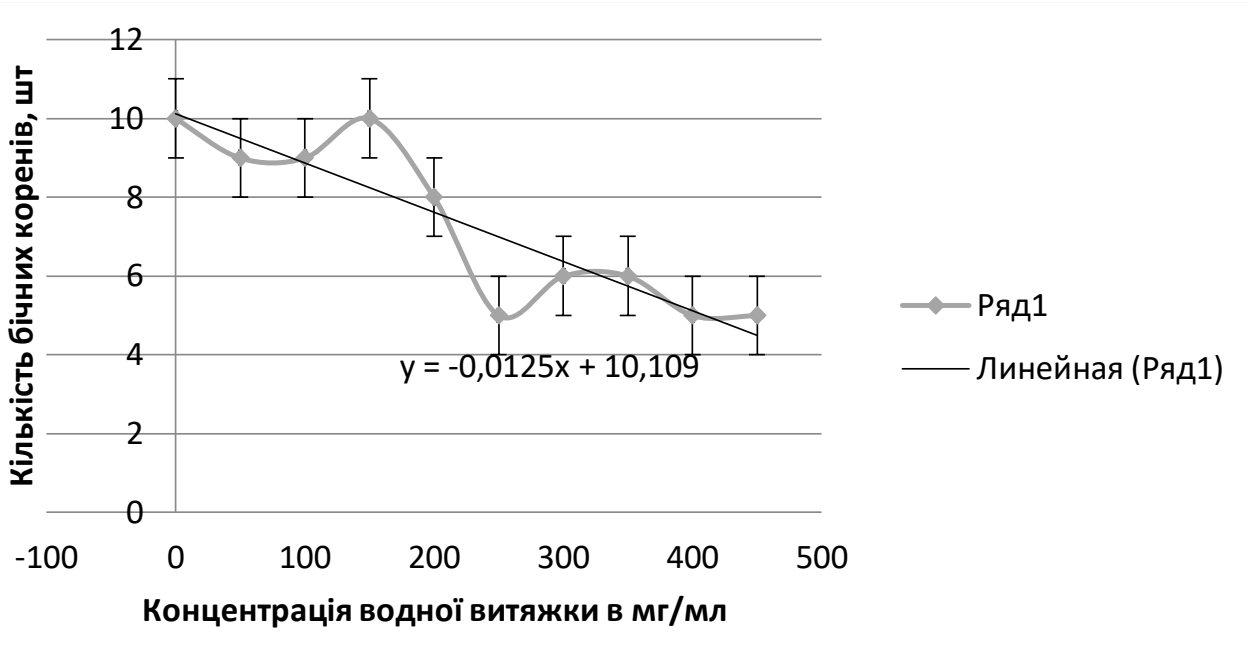

Рис.4. Цитостатична активність водної витяжки грабу звичайного.

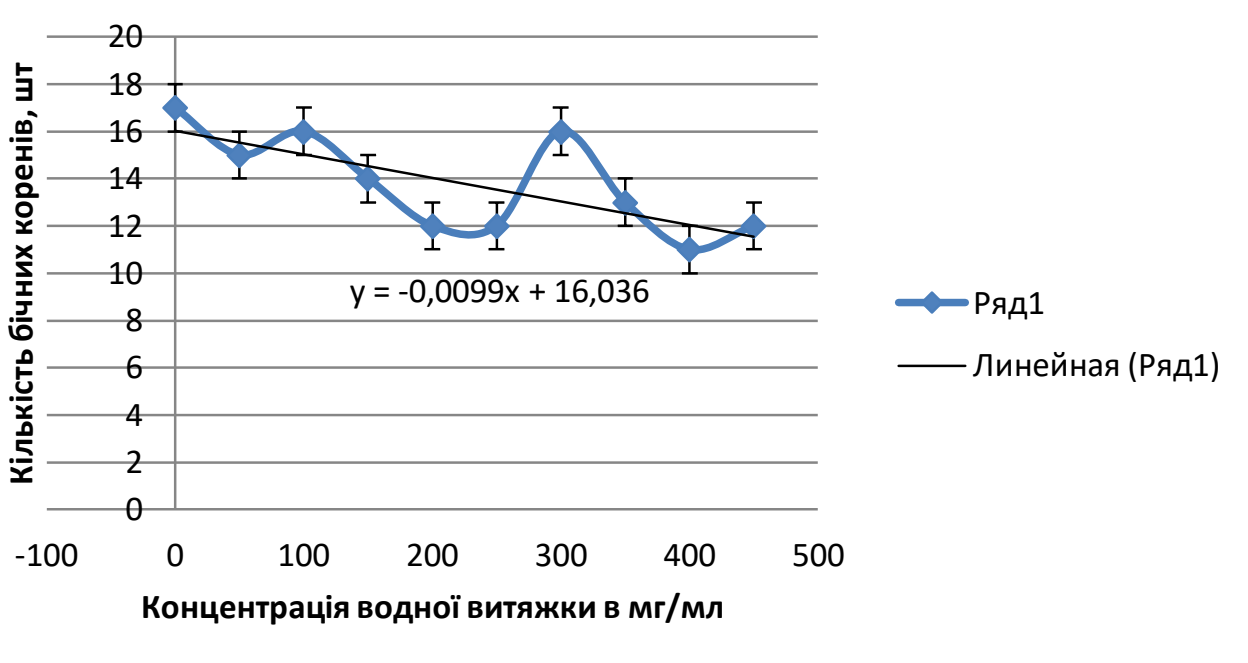

Рис.5. Цитостатична активність водної витяэски клена гостролистого.

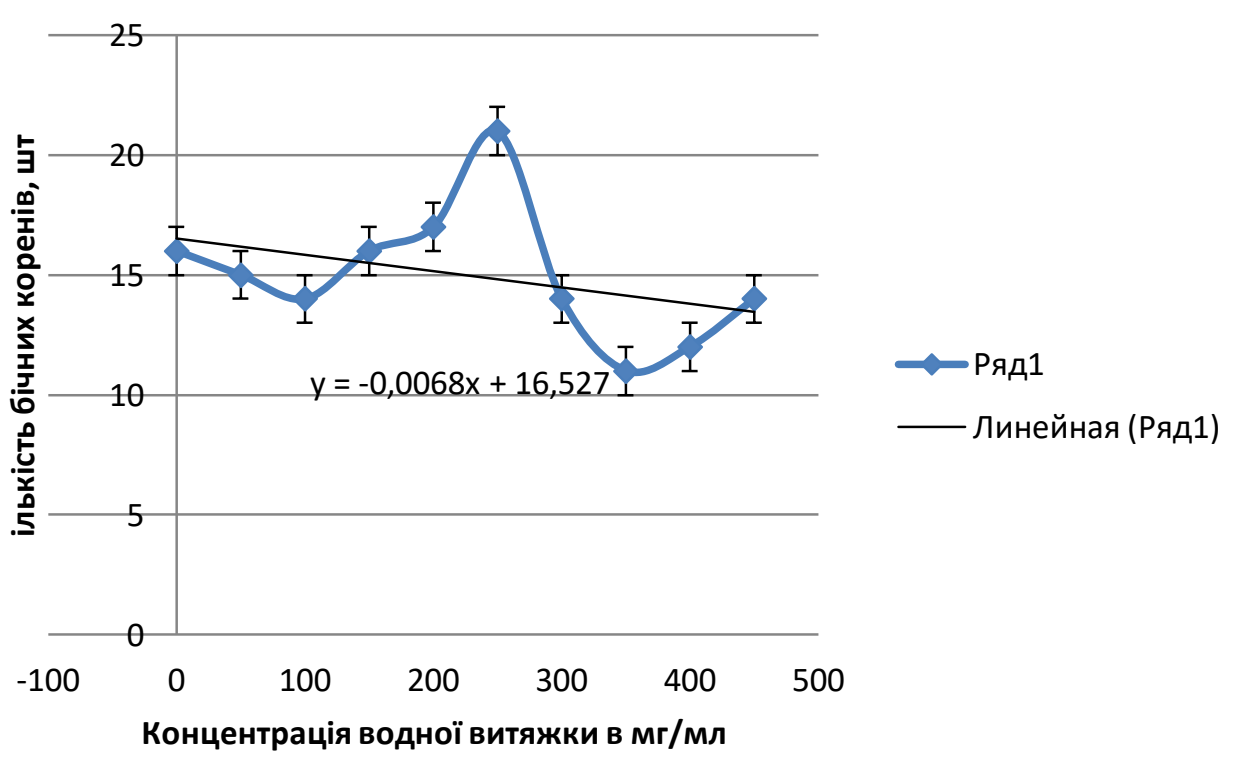

Рис.6. Цитостатична активність водної витяжки липи сериелистої. 


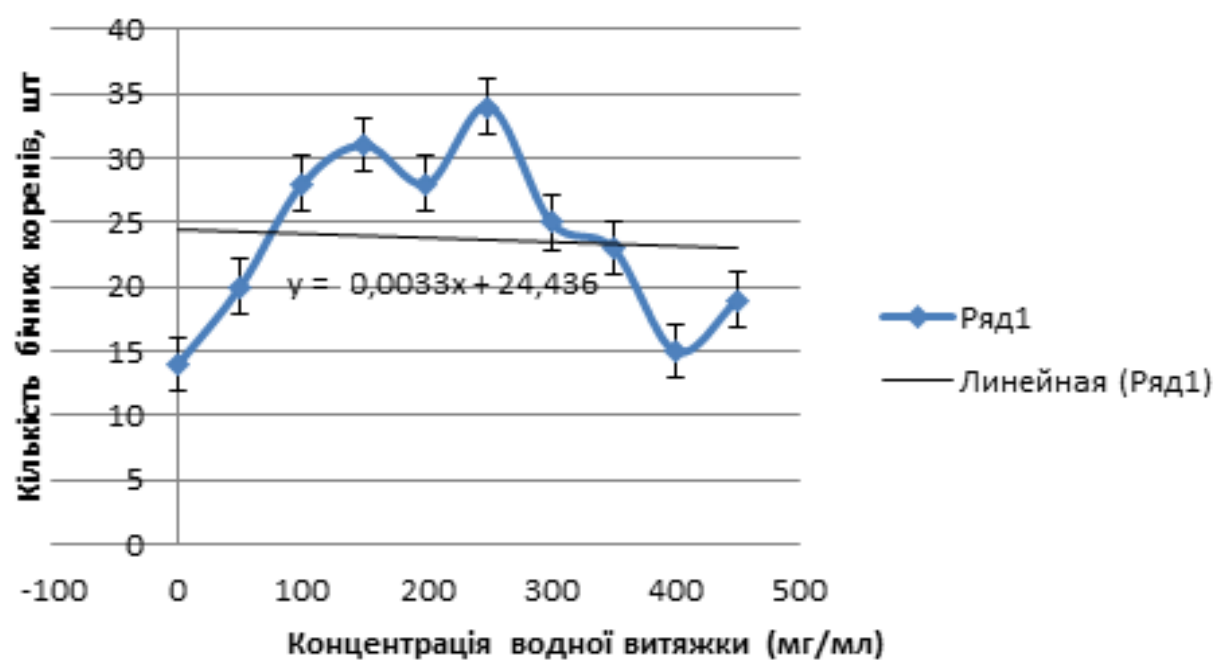

Рис. 7. Цитостатична активність водної витяжки сосни звичайної.

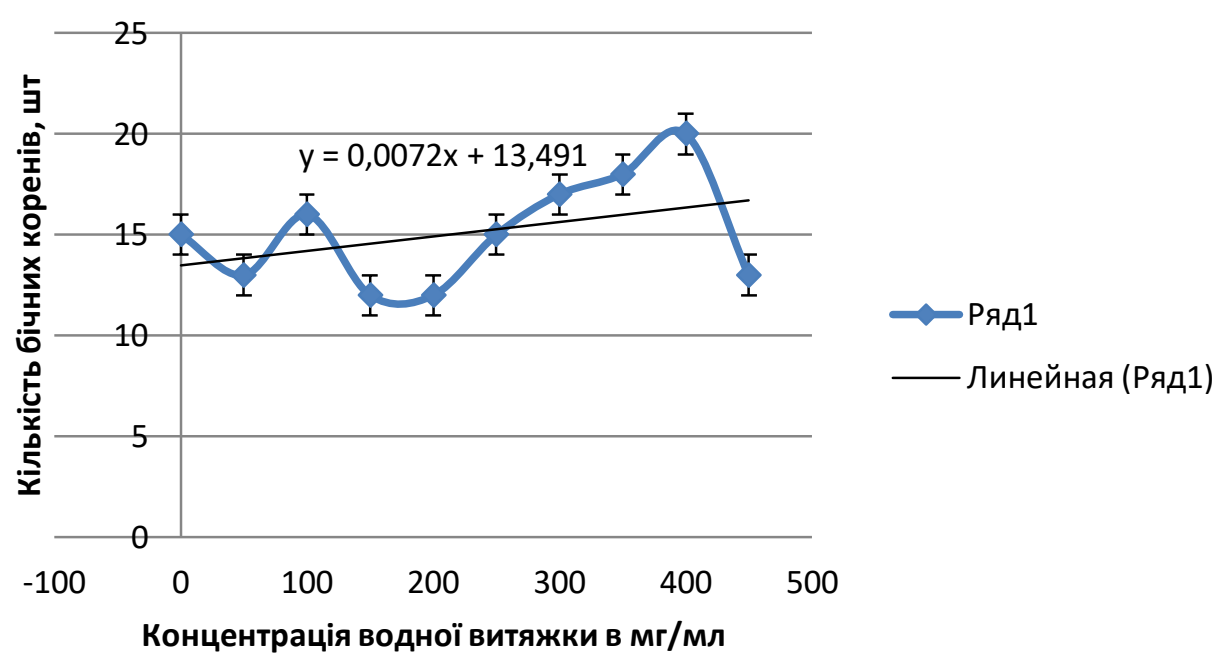

Рис. 8. Цитостатична активність водної витяжки дуба звичайної.

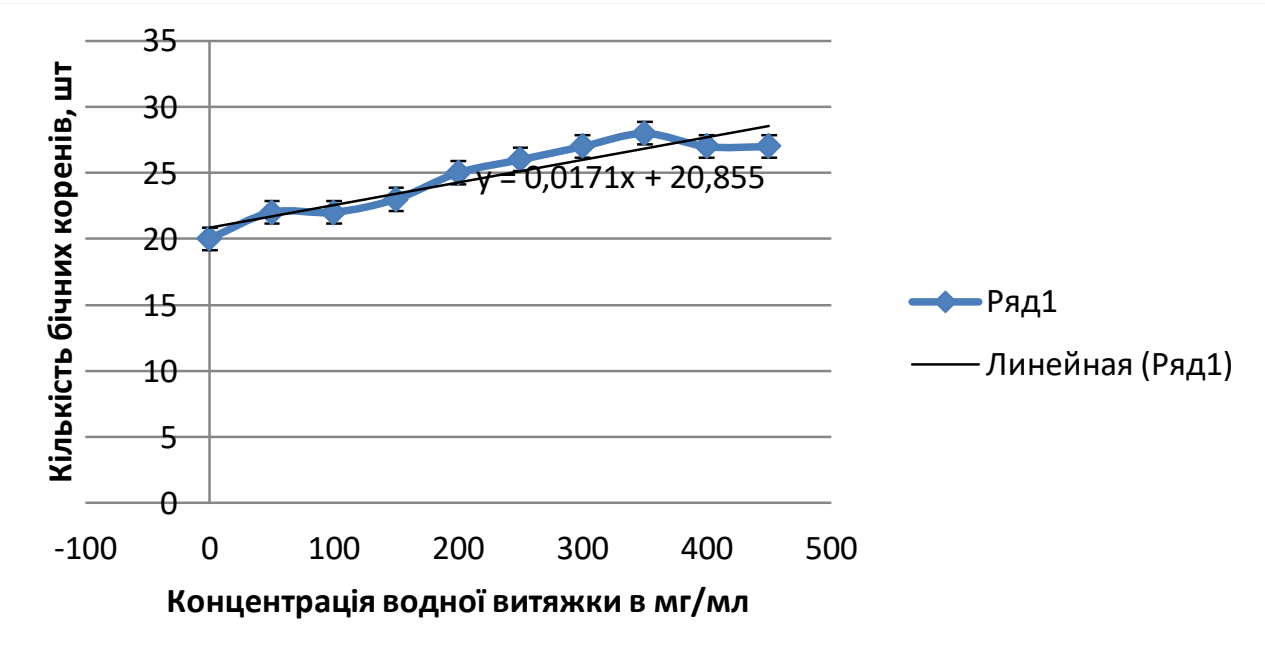

Рис.9. Цитостатична активність водної витяжки ялини звичайної.

Водні екстракти дуба звичайного та ялини звичайної стимулюють проліферацію клітин тест-об'єкта (Рис. 8 та Рис. 9). 
Для порівняння впливу водних екстрактів одних рослин на мітотичний поділ клітин інших нами було запропоновано до кривих цитостатичної активності проводити лінію тренду та обчислювати рівняння відповідної прямої. В зазначеному рівнянні, загальний вигляд якого $\mathrm{y}=\mathrm{Kx} \pm \mathrm{b}$ найважливішим $\epsilon$ показник $\mathrm{K}$ - це тангенс кута нахилу прямої тренда до вісі ОХ. Це зміна інтенсивності поділу клітин в залежності від концентрації. Якщо цей показник менше 0 , то відповідна витяжка має властивості інгібітора проліферації. Якщо К>0, то витяжка має ефект стимулятора проліферації. Відповідно до гіпотези нашого дослідження в одному фітоценозі можуть буги рослини, які або є стимуляторами проліферації, або одна з рослин- стимулятор, а інша інгібітор поділу клітин.

Одним із завдань нашого дослідження було створення алелопатичного показника фітотоксичності в фітоценозах деревних рослин. На наш погляд таким показником може бути коефіцієнт К в рівняннях прямих трендів та форма кривої цитостатичної активності, але за умови однакових параметрів G, Р, Н відповідно до рівняння Г.М. Висоцького.

Результати експерименту доводять гіпотезу дослідження. Наприклад, відповідно до літературних джерел похідним насадженнями борів $є$ березняки [5]. Водна витяжка сосни звичайної демонструє ефект стимулятора проліферації в концентраціях від 50 до 300 мг/мл, в той час як береза в межах цих же концентрацій виступає інгібітором проліферації. Фітоценологічну толерантність цих порід можна пояснити нівелюванням протилежного впливу берези та сосни на інтенсивність мітотичного поділу кореневої меристеми. При цьому водна витяжки з сосни звичайної в деякій мірі стимулює проліферацію, а клен і граб є інгібіторами. Також в соснових борах велика імовірність зростання ялини [5], що можна пояснити ефектом взаємодії: стимулятор - стимулятор, для сосни значенням тангенса кута складає $+0,0033$, а для ялини $+0,0171$. Також в соснових борах можуть зустрічатися клен гостролистий та граб звичайний, при цьому витяжка з сосни звичайної демонструє дію стимулятора проліферації, в той час як клен гостролистий та граб звичайний виступають у ролі інгібітора проліферації.

В природних умовах дуб зустрічається 3 домішками широколистяних порід (береза бородавчаста, клен гостролистий, граб звичайний) [6], та з хвойними породами (сосна звичайна, ялина звичайна). В цих ценозах також простежується взаємодія стимулятор-інгібітор (пари дубклен, дуб-граб, дуб-береза) та взаємодія симулятор-стимулятор (дуб-ялина, дуб-сосна).

Фітоценоз дуба звичайного та липи серцелистої теж відповідає парній взаємодії стимуляторінгібітор. Таку ж парну кореляцію можна спостерігати у фітоценозах осики звичайної з сосною та дубом.

Висновки. 1. Результати експериментальних досліджень продемонстрували, що високу фітотоксичну активність має водний екстракт осики звичайної та берези бородавчастої.

2. Сильним інгібітором проліферації є водний екстракт осики звичайної та білої акації. Витяжка з грабу звичайного проявляє властивості інгібітора проліферації в концентрації речовини вище 150 мг/мл. Екстракт з клена гостролистого демонструє слабкий ефект інгібітора проліферації.

3. Властивості стимуляторів проліферації мають водні екстракти ялини звичайної, дубу звичайного, сосни звичайної, липи серцелистої.

4. Результати дослідження дозволяють пропонувати параметр К (зміна інтенсивності поділу клітин тест-об'єкта в залежності від концентраціі) для прогнозування взаємовідносин деревних порід в межах фітоценозу. Відповідно до параметра К можна скласти наступний ряд фітотоксичної активності деревних порід: Populus tremula, Betula pendula, Robinia pseudoacacia, Carpinus betulus, Acer platanoides, Tilia cordata, Pinus sylvestris.

5. Вивчення кореляції між видовим складом фітоценозів природних угрупувань та параметрами кривих фітотоксичності дозволяють зробити висновок, що в природних фітоценозах угруповуються породи за принципом: інгібітор-стимулятор проліферації, або за принципом стимулятор-стимулятор.

6. Таким чином, результати дослідження дозволяють обговорювати питання про можливість введення параметра коефіцієнт фітотоксичності для визначення алелопатичного впливу в системі «рослина-рослина».

\section{ЛІТЕРАТУРА}

1. Иванов В.Б. Использование корней как тест-обьектов для оценки биологического действия химических соединений. Физиология растений 2011. Т. 58, №6. 944-952

2. Остапенко I.M., Марунич I.В. Алелопатичний вплив Ehinacea purpurea (L.) Moench та Betonica peraucta Klokov на деякі тест-культури. Відновлення порушених природних екосистем: Матеріали Третьої міжнародної конференції Донецьк, 2008. 226-232.

3. Райс Э. Аллелопатия. М., 1978. 392 с.

4. Свириденко В.С., Бабіч О.Г. Киричок Л.С. Лісивництво. К., 2005. 563 с.

5. Швиденко А.Й. Лісівництво. Чернівці, 2004. 302 с.

6. Швиденко А.Й. Лісознавство. Чернівці, 2001. 354 с. 